
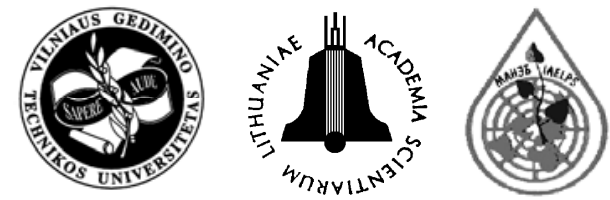

JOURNAL OF ENVIRONMENTAL ENGINEERING

AND LANDSCAPE MANAGEMENT

2010

18(3): 234-241

\title{
ON THE PROBLEM OF TERRITORIAL DISTRIBUTION OF SAMPLE AREAS FOR LANDSCAPE MONITORING PURPOSES
}

\author{
Margarita Jankauskaité ${ }^{1}$, Darijus Veteikis ${ }^{2}$ \\ ${ }^{1}$ Institute of Geology and Geography, T. Ševčenkos g. 13, LT-03223 Vilnius, Lithuania \\ ${ }^{2}$ Vilnius University, Faculty of Natural Sciences, M. K. Čiurlionio g. 21/27, LT-03101 Vilnius, Lithuania \\ E-mail: ${ }^{1}$ jankauskaite@geo.lt; ${ }^{2}$ darijus.veteikis@geo.lt \\ Submitted 03 Jun. 2009; accepted 20 Nov. 2009
}

\begin{abstract}
Today landscape change monitoring becomes important in the field of sustainable development planning. Real changes of landscape have to be observed in a large scale (not smaller than 1:10,000) in order to avoid generalization of small landscape elements. In such a scale it is rational to perform the monitoring in sample areas that would be enough statistically abundant. The paper offers an original method of distributing the landscape sample areas in Lithuanian territory, differing from most methods based on random choose of sample areas though thorough analysis of the analogous methods abroad was performed. The work was sponsored by the Environmental Agency at the Lithuanian Ministry of Environment. In accordance to the spread of different natural landscape types (like clayey plains, morainic hills, sandy plains, etc.), a set of 100 sample areas $\left(2.5 \mathrm{~km}^{2}\right.$ each) was distributed in Lithuanian territory. To increase the sample area number in smaller landscape types (spit, coastal sandy plain, delta), some proportional corrections were made. Thus, the largest number of the sample areas was assigned to the most spread clayey plains (22), the smallest number - to sandy coastal plain (3). In order to find a concrete place for each sample area inside the landscape type a computer program was employed and the highest representation principle applied. Several tens of thousands possible positions of the sample areas were tested in order to find the best in representing land cover structure. This was achieved by calculating relative remoteness of tested samples' land cover structure from the respective landscape type structure, further selecting the most patchy samples. Selecting the position of a sample area was also influenced by the buffer capacity (resistance to the chemical impact) of landscape, mostly concentrating on the areas with less buffer capacity (more sensitive to chemical pollution).
\end{abstract}

Keywords: landscape monitoring, sample areas, best representation principle, land cover structure, natural landscape types.

\section{Introduction}

Environmental monitoring divided into several directions like air, water, soil, biodiversity, and other components of landscape are being performed already for several years in various locations of Lithuania and already giving enough stuff for scientific generalization and data application (Bimbaitè, Girgždienè 2007). In addition to the monitoring of separate components, there is a great need of territorial (landscape) change monitoring, in many cases including land use or land cover observations in the whole state territory (like pan-European CORINE mapping) or using field observations in sample areas. Landscape mosaic, though being at the focus of landscape ecology investigations (Forman 1995; Farina 2000; Naveh, Lieberman 1990), does not comprise the third dimension, or relief, gravity caused and many other processes, however. Therefore, in the future true integrated landscape monitoring should include field observations of critical components of landscape (Sochava 1978; Veteikis, Jankauskaite 2006): biomass, humidity, effective radiation and anthropogenic load. Some methodological experience is already accumulated several decades ago while landscape monitoring at a stationary site (Gidrologicheskiye ... 1970, 1988) as well as creating methodologies for evaluating landscape resistance to chemical and physical impact (Pauliukevičius and Grabauskienè 1989, Pauliukevičius and Grabauskienè 1993; Baubinas 1993). For today situation, however, land cover, that is reflecting the land use, seems to be the most effective and informative indicator of landscape changing processes. Land use change data later can be used for many scientific or applied purposes, because this is an indicator of both processes of landscape evolution in general (combining natural and cultural factors) and pointer to the current subsequent processes in the matter and energy flows (Okoński 2007; Lathrop et al. 2007).

Monitoring of landscape transformation has been gaining scientific weight for seeking to insure a sustainable coexistence of the natural environment and humanity. The correctness of collecting data about landscape transformations can be secured by an appropriate monitoring methodology. The actual landscape transformations across Lithuania must be recorded at a large scale without omitting and generalizing the small land use elements small groves, bogged up or overgrown by bushes field spots, solitary overgrowths of shrubs, individual homesteads and other minor landscape elements - which usually are ignored in the smaller (less than 1:100000) scale maps like in CORINE land cover. 
The reliability of the data about landscape transformations would be best secured when determined using ortophoto images (at a scale 1:10 000) covering the entire territory of Lithuania. Yet the inventory of the total area of the country (65.3 thou $\mathrm{km}^{2}$ ) would be time-consuming and costly and it could be more rational to monitor only certain selected territories, the so-called sample areas or just samples, the number of which should be statistically reliable for proper analysis. The landscape transformations in the sample areas could be traced using the mentioned ortophoto images at a scale 1:10 000 .

The article introduces an original method of distributing the sample areas of landscape monitoring in the territory of Lithuania. It is much more detailed both in regard of number of sample areas and diversity of chosen landscape types than in the previous attempt (Bauža 2007). It should be added that the proposed method was employed in practice during the first attempt to determine landscape transformations in the years between 1975-1977 (the middle of the Soviet period) and 2005-2006 when the last aerophotograph of the territory of Lithuania was made. The study was accomplished by support of the Environmental Agency at the Lithuanian Ministry of Environment. The method was worked out also taking into consideration the foreign experience (Brandt et al. 2002; Smith, Wyatt 2007; Roose et al. 2007; Aaviksoo, Muru 2008; Banko et al. 2002; Developments ... 2004; Gulbinas et al. 2003; Löfgren et al. 2002; Monitoring information 2000; Wrbka 2000; Peterseil et al. 2004).

\section{Methods}

It is suggested that the number, size and location of sample areas for landscape monitoring were determined basing on the principle of highest representation. In other words, the obtained landscape transformation data should represent various types of landscape and various regions of the country.

It is suggested to take a reasonable number of 100 sample areas $2.5 \mathrm{~km}^{2}$ each - distributed in proportion to the area occupied by landscape types (the largest landscape type gets the greatest number of sample areas: e.g. clayey plains get 22 sample areas, sandy plains 13, the spit 5, etc.).

It is plausible that territorial transformations are reflected more reliably by many small than a few larger sample areas. For this reason, the chosen number of landscape monitoring sample areas is 100 . The area covered by them is $250 \mathrm{~km}^{2}$. Each of the sample areas would occupy approximately $2.5 \mathrm{~km}^{2}$. For the purposes of standardization, a square is the chosen shape of the sample areas (the side length is $1581 \mathrm{~m}$ ). The chosen size of sample areas also is convenient in terms of work organization: at a scale 1:10 000, a sample area is represented by a square sized $16 \times 16 \mathrm{~cm}$ which can be easily placed on a sheet A4.

Stratification or distribution according to the types of territories is another important point in distinguishing the sample areas. Following the principle of best representation, 100 sample areas had to be distributed in proportion to landscape types according to the country's area occupied by them. The distribution is demonstrated in Table 1 (column G).

Nine generalized types of landscape were distinguished by combining the main natural types of landscape mapped as physiomorphotops (Lietuvos Respublikos ... 2006). The total of 11 landscape types (generalized into 9) occupying $86 \%$ of Lithuania's territory will be represented by the program. Column $G$ (Table 1 ) indicates the number of sample areas in case of application of direct proportionality (dependening on the area occupied) function. In that case, the "small" types (delta, spit and Coastal Plain landscapes) would receive 0 sample areas. Yet their importance requires representation. So the correction was made in order to increase the sample number in these "small” landscapes (decreasing sampling units in wide spread landscape types).

Table 1. Distribution of the number of sample areas according to the main landscape types

\begin{tabular}{l|l|l|l|l|l|l}
\hline No & $\begin{array}{c}\text { Generalized landscape } \\
\text { types }\end{array}$ & $\begin{array}{c}\text { Number of } \\
\text { physiomorphotope } \\
\text { sub-regions }\end{array}$ & Area, $\mathrm{km}^{2}$ & $\begin{array}{c}\text { Portion of } \\
\text { Lithuanian } \\
\text { territory, \%. }\end{array}$ & $\begin{array}{c}\text { Number of sample } \\
\text { areas (direct propor- } \\
\text { tionality) }\end{array}$ & $\begin{array}{c}\text { Number of sample } \\
\text { areas (corrected } \\
\text { proportionality) }\end{array}$ \\
\hline $\mathbf{A}$ & \multicolumn{1}{|c|}{$\mathbf{B}$} & $\mathbf{D}$ & $\mathbf{E}$ & $\mathbf{F}$ & $\mathbf{G}$ & $\mathbf{H}$ \\
\hline 1 & Clayey downy plains & 27 & 11002.5 & 16.64 & 19 & 17 \\
\hline 2 & Delta valley and delta & 3 & 238.4 & 0.36 & 0 & 4 \\
\hline 3 & Lake terrains & 7 & 2535.1 & 3.83 & 4 & 9 \\
\hline 4 & Morainic hills & 21 & 9974.4 & 15.09 & 17 & 16 \\
\hline 5 & Sandy plains & 20 & 5527.3 & 8.36 & 10 & 13 \\
\hline 6 & Clayey plains & 28 & 23862.4 & 36.10 & 42 & 22 \\
\hline 7 & Spit & 2 & 101.4 & 0.15 & 0 & 5 \\
\hline 8 & Sandy coastal plain & 1 & 189.1 & 0.29 & 0 & 3 \\
\hline 9 & Valleys & 16 & 3966.6 & 6.00 & 7 & 11 \\
\hline & Total of types & $\mathbf{1 2 5}$ & $\mathbf{5 7 3 9 7 . 2}$ & $\mathbf{8 6 . 8 3}$ & $\mathbf{1 0 0}$ & $\mathbf{1 0 0}$ \\
\hline
\end{tabular}


The distribution of sample areas in different landscape types should be followed by selection of concrete sites for them. In many Western countries, the sample areas for landscape monitoring are "scattered" in a random way aiming for the objectiveness of the data obtained. The representation in the mentioned case is achieved by a large number of sample areas creating conditions for reliability of statistical data. Authors suggest a different pathway. It is taken into account that the number of sample areas amounting to 3-5 in some types of landscape may not be reliable if chosen randomly because a strong probability of missing some important elements of landscape structure occurs.

For higher representation, the locations that are most comparable with the average structure of appropriate landscape type were chosen. The CORINE (2000) data base of land cover and the Map of Geochemical Toposystems were used for this purpose. The first step included determining the structure of the land cover (according to the CORINE classification and data base) for each landscape type.

The further steps included the employment of a special computer program (the author A. Kryžanauskas) developed as ArcGis program module. It was based on the principle of sample area "striding" (Fig. 1) across a territory and automatically counting the structure of land cover in per cents. The technical possibilities and program limitations allowed checking from a few hundred (in smaller landscape types) to a few tens of thousand (in large landscape types) locations of sample areas (Table 2). Area occupied by the landscape type was the criterion to decide the size of striding step. For large and compact landscape types it was equal $1 \mathrm{~km}$, for smaller and narrow (like coastal plain, spit, delta and valleys) $-0.5 \mathrm{~km}$. The total of 67758 possible locations of sample areas in various types of landscape were checked. This statistically rather large number of locations offered a wide scope for choice of sample areas: the territory of Lithuania amounts to about $65300 \mathrm{~km}^{2}$ what means more than one sample area per $1 \mathrm{~km}^{2}$; bearing in mind that one sample area occupies $2.5 \mathrm{~km}^{2}$, the territory of Lithuania was covered more than 2.5 times.

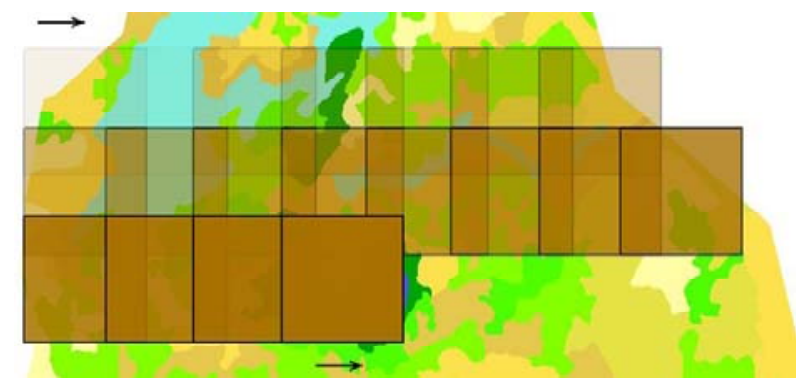

Fig. 1. Principle scheme of sample area "striding" across the chosen natural type of landscape

The process of programmed striding included delineation of square shaped $2.5 \mathrm{~km}^{2}$ area in each of the mentioned almost 68 thousand locations. These provisional areas created by "striding” can be called pseudo-sample areas or pseudo samples, emphasizing their transitional and temporary purpose.

The next stage included comparison of the structure of land cover in each pseudo-sample and a respective landscape type by calculating 'remoteness' (formula 1):

$$
D=\sum_{j}\left|z_{j}-Z_{j}\right|,
$$

where $D$ - relative remoteness of the land cover structure in a pseudo sample from the respective type of landscape (index of structural remoteness) measured in $\%, j-$ number of the type of land cover (the total number of land cover types according to CORINE is 30 ); $z_{j}$ - percentage of $j$ land cover type in a pseudo sample, $Z_{j}$ - percentage of $j$ land cover type in a respective landscape type.

For instance, if the percentage of each land cover type in a pseudo sample differs from the structure of landscape type by more than 1 per cent the remoteness index $D$ will equal 30 . The higher the index the greater the differences between the land cover of pseudo sample area and landscape type and the lower the probability that this pseudo sample area will be chosen as a true sample area. Thus choosing sample areas, index $D$ (its smallest values) becomes a decisive one.

For testing purposes index $D$ was calculated for each pseudo sample, i.e., 67758 times. One of these steps is presented in Fig. 2.

Table 2. Number of sample area locations checked for the structure of land cover in different landscape types

\begin{tabular}{c|l|c|c}
\hline No & Generalized landscape types & Number of sample areas & Number of checked locations of sample areas \\
\hline 1 & Clayey downy plateaus & 17 & 11265 \\
\hline 2 & Delta & 4 & 237 \\
\hline 3 & Lake terrains & 9 & 2555 \\
\hline 4 & Morainic hills & 16 & 10605 \\
\hline 5 & Sandy plains & 13 & 5550 \\
\hline 6 & Clayey plains & 22 & 27518 \\
\hline 7 & Spit & 5 & 407 \\
\hline 8 & Coastal Plain & 3 & 737 \\
\hline 9 & Valleys & 11 & 8884 \\
\hline & Total & $\mathbf{1 0 0}$ & $\mathbf{6 7 7 5 8}$ \\
\hline
\end{tabular}




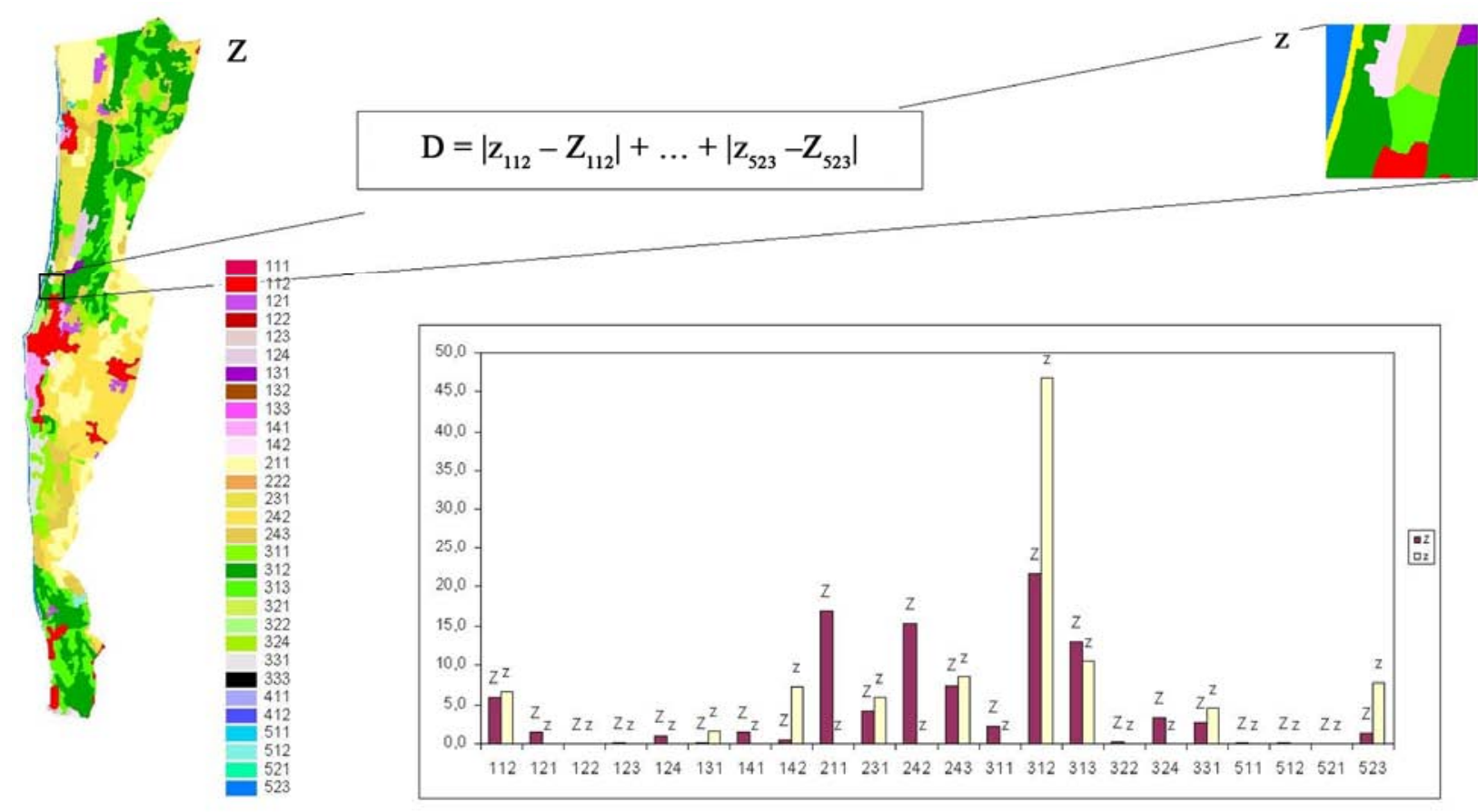

Fig. 2. Calculation procedure for the index of remoteness of structures between landscape type (marked by $Z$ ) and pseudo sample (marked by $z$ ). The total sum of all the differences between $z$ and $Z$ of each land cover type (112 to 523), present in a particular landscape type, is calculated

It should be noted that the mentioned index not always correctly reflects the similarities/differences between the structures of land cover in sample areas and landscape types. If the structure of landscape type has small types of land cover occupying $0.1-5 \%$ of the total area and pseudo sample has no such type of land cover, these few per cents will easily hide and will not be noticed when choosing sample areas.

In order to perform the selection of sample areas more correctly a few additional indices are taken into account. One of them is the number of the types of land cover (patchiness) in a pseudo sample area. It has been proved in practice that pseudo sample areas as small territories $\left(2.5 \mathrm{~km}^{2}\right)$ never have as many types of land cover as landscape types. The most patched pseudo sample areas have $30-50 \%$ types of land cover characteristic of respective landscape type. In this case most patched pseudo sample areas with the smallest $\mathrm{D}$ value answer the principle of representation best.

Selection of best representing samples in a long list of pseudo samples requires one more limiting operation: only those pseudo sample areas are considered that include not less than $95 \%$ of respective landscape type. Partial pseudo samples appear in a "striding" process when program traces all possible locations of sample areas if their centre hits the indicated landscape type. During the described operation, a large number of pseudo sample areas fall off depending on the configuration of landscape type. This happens on the edge of landscape type and in the narrow places of landscape areas: valleys, spit, delta valley, and Coastal Plain, i.e. the types of landscape occupying small parts of the total territory. This reduction of pseudo samples' number, however, doesn't threat the width of sample choice.

For final selection of sample location, distributions of geochemical toposystems inside each landscape type were taken into consideration. Each landscape type can have territories with different qualities of resistance to chemical impact. The principle of highest representation was followed and a certain number of sample areas matching the buffer potential of every geochemical system was distinguished (confining to the previously established number of sample areas for landscape types) depending on the percentage of dominant geochemical toposystems in landscape types (Table 3).

As per Table 3, some geochemical toposystem buffer potential levels do not occur in several landscape types. On the other hand, the especially high buffer potential not only is rare but also of less importance (because geochemical toposystems with high buffer potential are most highly resistant or least sensitive to chemical impacts). For this reason, only one sample area representing especially high buffer capacity was distinguished and was attached to widespread clayey plains type. In other landscape types, sample areas of this buffer potential were not chosen concentrating them in more vulnerable toposystems. When the number of areas with high and low buffer potential is equal, priority was given to the ones with low potential marked by higher landscape vulnerability. Thus the greatest number of sample areas was distinguished in the most widespread territories with average and low buffer potential: 29 and 28 respectively. Due to especially high vulnerability, even 9 sample areas from different landscape types will represent the especially low buffer potential though it is not widespread in the territory of Lithuania. 
Table 3. Proposed distribution of sample number in landscape types taking into account the percentage of geochemical toposystems according to buffer potential

\begin{tabular}{|c|c|c|c|c|c|c|c|c|}
\hline \multirow[b]{2}{*}{ Main landscape types } & \multicolumn{7}{|c|}{ Buffer potential of geochemical toposystems } & \multirow[b]{2}{*}{$\begin{array}{c}\text { The total } \\
\text { number of } \\
\text { sample areas }\end{array}$} \\
\hline & $\begin{array}{l}\text { especially } \\
\text { high } \\
\text { buffer } \\
\text { potential }\end{array}$ & $\begin{array}{l}\text { very high } \\
\text { buffer } \\
\text { potential }\end{array}$ & $\begin{array}{c}\text { high } \\
\text { buffer } \\
\text { potential }\end{array}$ & $\begin{array}{c}\text { average } \\
\text { buffer } \\
\text { potential }\end{array}$ & $\begin{array}{c}\text { low buffer } \\
\text { potential }\end{array}$ & $\begin{array}{l}\text { very low } \\
\text { buffer } \\
\text { potential }\end{array}$ & $\begin{array}{l}\text { especially } \\
\text { low buffer } \\
\text { potential }\end{array}$ & \\
\hline Clayey downy plateaus & & 1 & 3 & 4 & 6 & 2 & 1 & 17 \\
\hline Delta & & & & 3 & 1 & & & 4 \\
\hline Lake terrains & & 1 & 1 & 3 & 2 & 1 & 1 & 9 \\
\hline Morainic hills & & 1 & 1 & 6 & 5 & 2 & 1 & 16 \\
\hline Sandy plains & & 1 & 2 & 3 & 5 & 1 & 1 & 13 \\
\hline Clayey plains & 1 & 2 & 6 & 7 & 3 & 2 & 1 & 22 \\
\hline - (including) karst region & & & 1 & 2 & & & & 3 \\
\hline Spit & & & & & & 2 & 3 & 5 \\
\hline Coastal Plain & & & 1 & & 2 & & & 3 \\
\hline Valley & & & 1 & 3 & 4 & 2 & 1 & 11 \\
\hline Total & 1 & 6 & 15 & 29 & 28 & 12 & 9 & 100 \\
\hline
\end{tabular}

\section{Results and discussion}

Result of the application of the methodology described above was distinguishing 100 sample areas in different landscape types with different level of resistance capacity to chemical impact (buffer potential). Paper limitations don't allow present each of the sample, however general facts and some of the most representative ones are given bellow.

It is difficult to trace any strict dependence between relative structural remoteness (index $\mathrm{D}$ described above) and landscape type or its size. Sample areas can be equally close and distant from the average land cover structure of their respective landscape types be it widely spread like clayey plain or being little spread or unique like a spit. Only delta and coastal plain samples are relatively more remote from average landscape type structures, D varying between 38 and 120\%, while D index of the other samples vary from 24 to $98 \%$. To remind, index D of the selected 100 samples is much lower than average of pseudo samples that were only a starting data array for selection.

Generally, selected samples representing large landscape types like clayey plains, clayey downy plateaus, morainic hills and sandy plains (total number - 68 out of 100) have more patchy land cover structure than the small and narrow landscape types like delta, coastal plain or spit (12 samples) (Figs. 3, 4). The patchiness in the first group of samples vary from 6 to 15 (averagely about 12) land cover patches per sample, while in the second - from 5 to 11 (averagely about 9).

The third group of samples (20 units) represent two special landscape types, related to hydrographical network, i.e. lake terrain and river valleys (Figs. 5, 6). They are the most patchy territorial units including from 8 to 17 (averagely about 13-14) land cover patches. This is related first of all to appearance of additional land cover types like water bodies and surrounding swamps, peatbogs or meadows. Besides that, larger hydrographical components are always related to more complicated relief forms increasing structural richness of land use.

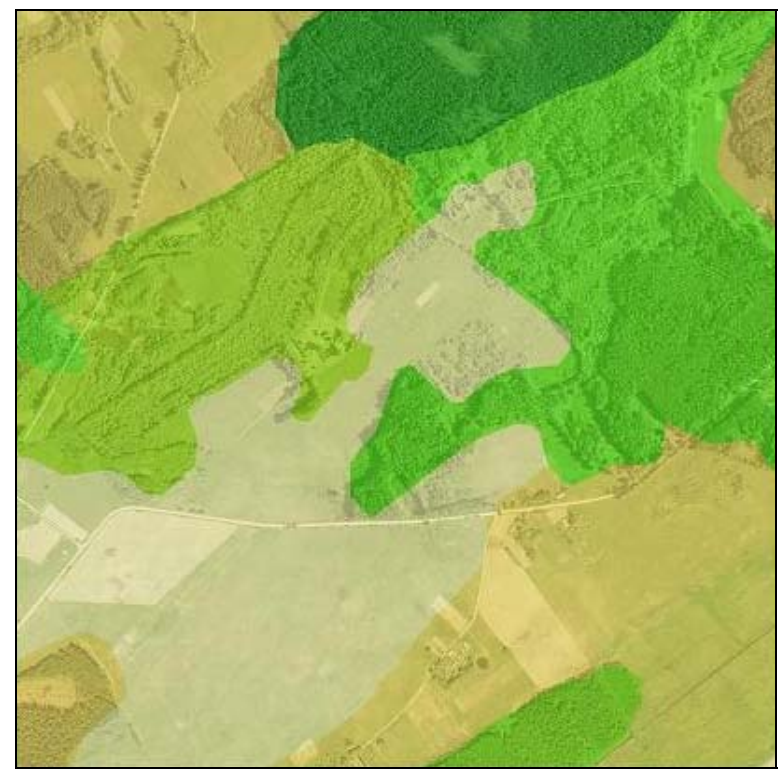

Fig. 3. Patchiness of clayey plain, sample No 65 (15 patches and 8 types of land cover, located in Rokiškis district). This sample represents a geosystem with low buffer potential*

Figures 3 to 6 show patchiness of samples calculated using rather small scale cartographic data (CORINE which is in scale of 1:100 000) and can give only general information useful for selecting sample locations. For landscape monitoring purposes, however, real patchiness should be evaluated and at much larger scale, like that in orthophoto images depicted bellow the colour cartoschemes of the mentioned figures. Mapping, vectorising and analysis of the large scale cartographic data in different historical periods are the other steps in landscape monitoring.

After all mentioned procedures, 100 sample areas scattered in different types of landscape of varying sensibility were distinguished (Fig. 7).

\footnotetext{
* Background orthophotos ORT10LT 2007 (C) National Land Service under Ministry of Agruculture of the Republic of Lithuania.
} 


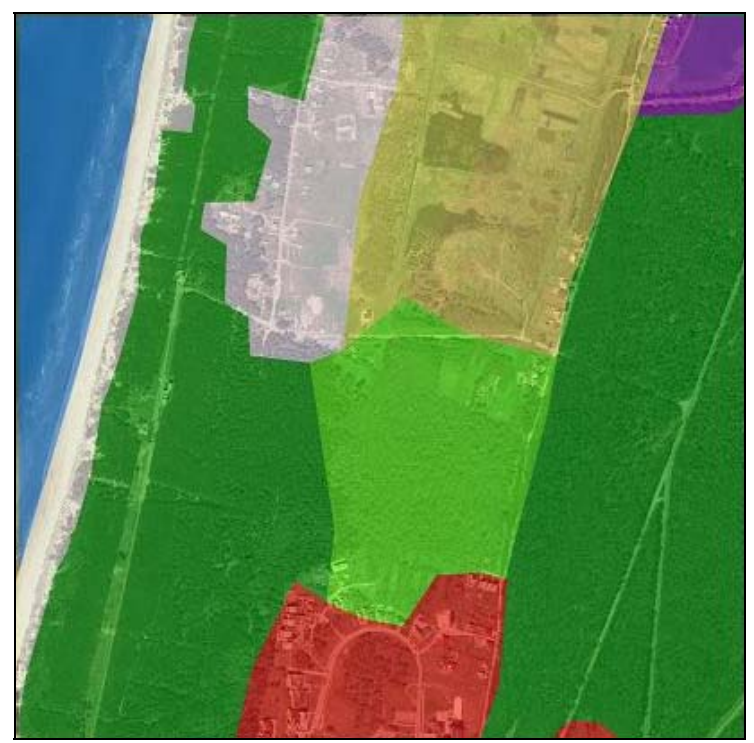

Fig. 4. Patchiness of coastal plain, sample No 89 (11 patches and 9 types of land cover, located near Palanga). This sample represents a geosystem with low buffer potential ${ }^{*}$

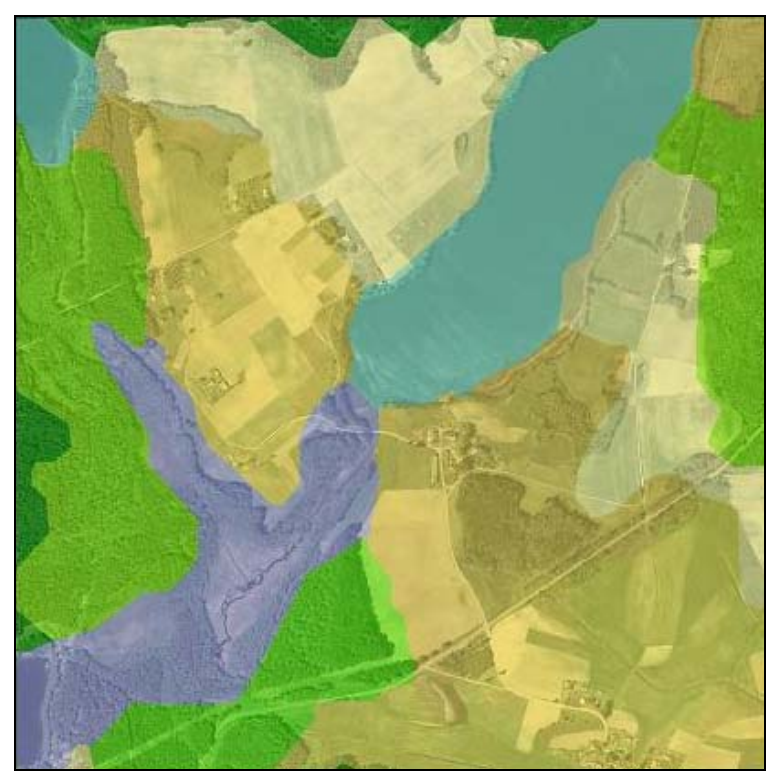

Fig. 5. Land cover structure of the most patchy (22 land cover patches, 9 types) selected sample (belonging to lake terrain landscape type, located in Lazdijai district, No 25). This sample represents a geosystem with average buffer potential ${ }^{*}$

\section{Conclusions}

1. Territorial transformations are best represented by large number of sample areas. For this reason, a set of 100 sample areas was chosen occupying approximately $2.5 \mathrm{~km}^{2}$ each. For standardization purposes, the sample areas represent squares (side length $1581 \mathrm{~m}$ ). Sample areas of this size are convenient in terms of organizing the work: at a scale $1: 10000$, it is a $16 \times 16 \mathrm{~cm}$ sized square which can be easily placed in a sheet A4.

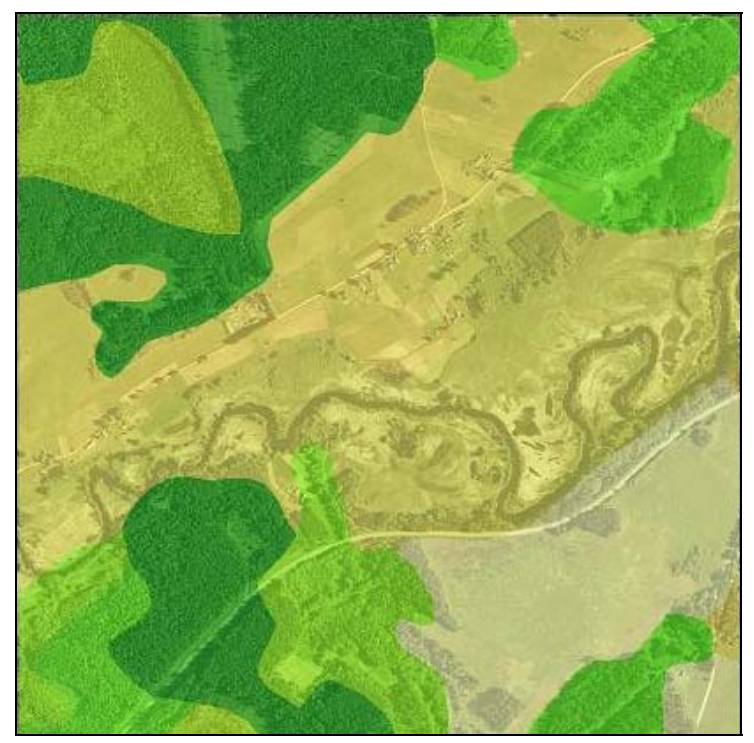

Fig. 6. The patchiest sample (No 96) selected from river valley landscape type (17 land cover patches, 7 types, located in Utena district). This sample represents a geosystem with low buffer potential $^{*}$

2. Taking into account the distribution of landscape types, the number of sample areas was shared-out proportionally, but due to presence of very little widespread landscape types (spit, delta and coastal area) proportions were additionally corrected. The greatest number of sample areas was attached to the most widespread clayey plains (22) followed by clayey downy plateaus (17) and morainic hills (16). The smallest number of sample areas (even purposefully increased) was attached to the coastal plain (3), delta (4) and spit (5). Other types of landscapes received from 9 to 13 samples.

3. The selection of sample areas was based on the principle of highest representation (instead of random distribution). For this purpose, a computer program was developed which helped to find the sites for sample areas best representing the land cover of various landscape types. For each landscape type, from a few hundred to a few tens of thousand possible locations of sample areas were checked for best representation of the structure of land cover and the number of the land cover patches.

4. Selection of sample areas also was related with the landscape buffer potential. In distinguishing the sample areas measures were taken to represent the territories with different buffer potential. Yet the sample areas were mainly concentrated in the territories of lower buffer potential (more sensitive to chemical pollution). Even 9 sample areas were distinguished in the rare territories with especially low buffer potential.

\footnotetext{
* Background orthophotos ORT10LT 2007 (c) National Land Service under Ministry of Agruculture of the Republic of Lithuania.
} 

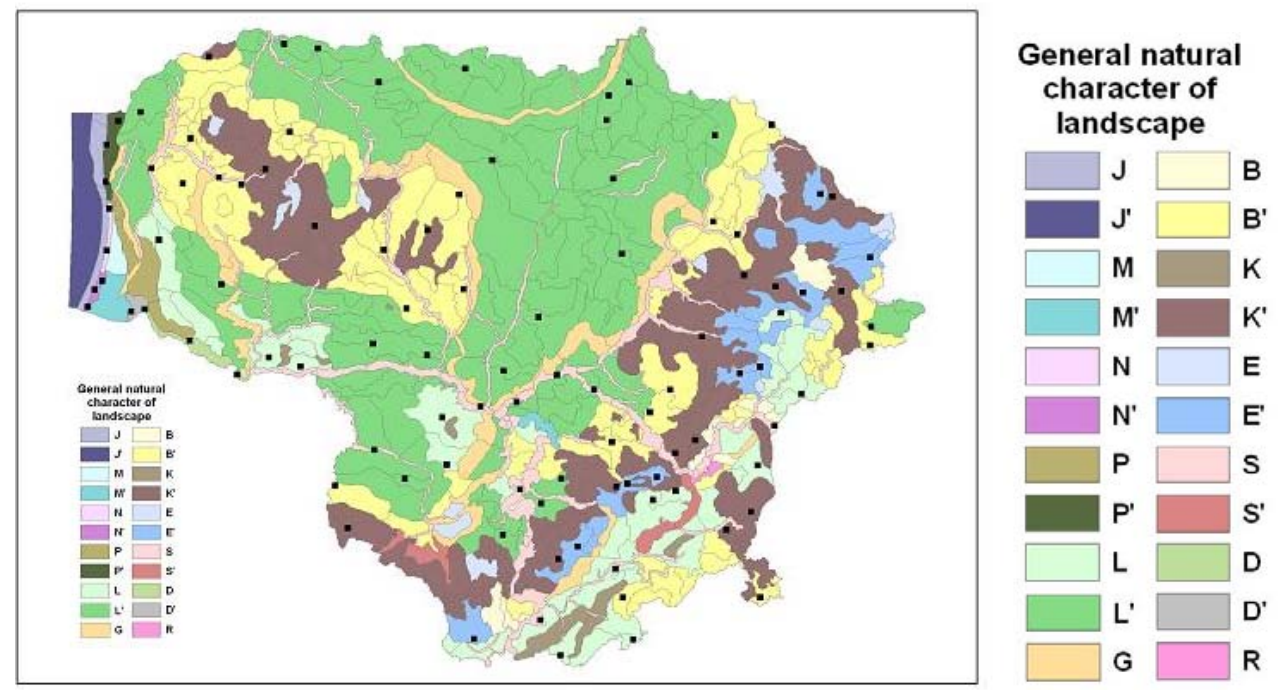

Fig. 7. Distribution of landscape sample areas (black squares) in different landscape types of Lithuania (map according to: Lietuvos Respublikos..., 2006). General natural character types of landscape: $\mathrm{J}$ - marine landscape in the coastal zone (at a depth of < $20 \mathrm{~m}$ ); $\mathrm{J}^{\text {‘ }}$ - underwater plateaus and troughs; $\mathrm{M}$ - shallow lagoon (at a depth of $<2 \mathrm{~m}$ ); $\mathrm{M}^{\star}$ - deep lagoon; $\mathrm{N}$ - smoothened spit; $\mathrm{N}^{\star}$ - rugged spit; P - lagoon coastal plain; $\mathrm{P}^{`}$ - sandy coastal plain; L - continental sandy plains; L` - clayey plains; B - sandy downy plateaus; $\mathrm{B}$ ` - clayey downy plateaus; $\mathrm{G}$ - morainic hills; $\mathrm{K}$ - sandy hills; $\mathrm{K}^{`}$ - morainic hills; $\mathrm{E}$ - troughs with lakes; E` - lake terrains; S - valleys; S‘ - old valleys; D - delta valley; D` - delta; R - erosion washes

\section{References}

Aaviksoo, K.; Muru, K. 2008. A methodology of the satellite mapping and monitoring of protected landscapes in Estonia, Estonian Journal of Ecology 57(3): 159-184.

Banko, G.; Zethner, G.; Wrbka, Th., and Schmitzberger, I. [online]. 2002 [cited 12 February 2009]. Landscape types as the optimal spatial domain for developing landscape indicators. Available from Internet: <http://webdomino1. oecd.org/comnet/agr/landscape.nsf/viewHtml/index/ \$FILE/AustriaBanko.PDF>.

Bauža, D. 2007. Estimation and trends of landscape transformation in the second half of the 20th century, Journal of Environmental Engineering and Landscape Management 15(2): 119-124.

Bimbaitè, V.; Girgždienė, R. 2007. Evaluation of Lithuanian air quality monitoring data applying synoptical analysis, Journal of Environmental Engineering and Landscape Management 15(3): 173-181.

Brandt, J. J. E.; Bunce, R. G. H.; Howard, D. C.; Petit, S. 2002. General principles of monitoring land cover change based on two case studies in Britain and Denmark, Landscape and Urban Planning 62: 37-51. doi:10.1016/S0169-2046(02)00095-6

Developments in strategic landscape monitoring for the Nordic countries [online]. 2004 [cited 12 February 2009]. Groom, G. (Ed.). Available from Internet: <http://www.norden.org/ $\mathrm{pub} / \mathrm{miljo} / \mathrm{miljo} / \mathrm{sk} / \mathrm{ANP2004705.pdf>}$.

Farina, A. 2000. Principles and Methods in Landscape Ecology. Dordrecht: Kluwer Academic Publ.

Forman, R. T. T. 1995. Land Mosaics: the Ecology of Landscapes and Regions. Cambridge University Press, Cambridge.

Gidrologicheskiye i geochimicheskiye svoistva erodirovannykh landshaftov [Hydrological and geochemical features of eroded landscapes]. 1970. Vilnius.
Gidrologicheskiye i landshaftno-geochimicheskiye aspekty funktsionirovaniya kholmistykh agrogeosistem [Hydrological and landscape-geochemical aspects of hilly agro-geosystems functioning]. 1988. Vilnius.

Gulbinas, Z.; Pileckas, M.; Petravičiūtè, R. 2003. Kraštovaizdžio monitoringo organizavimo problematika. 1 . Šiaurès Europos šalių patirtis, Geografijos metraštis 36(1): 225-236.

Lathrop, R. G.; Tulloch, D. L.; Hatfield, C. 2007. Consequences of land use change in the New York-New Jersey Highlands, USA: Landscape indicators of forest and watershed integrity, Landscape and Urban Planning 79: 150-159. doi:10.1016/j.landurbplan.2006.02.008

Lietuvos Respublikos kraštovaizdžio erdvinès struktūros ìvairovès ir jos tipu identifikavimo studija [Study of landscape spatial structure diversity and its types identification of Lithuanian Republic] [online]. 2006 [cited 18 November 2009]. Available from Internet: <http://www.am.lt/VI/index.php\#a/6033>.

Löfgren, P.; Fridman, J., and Ringvall, A.; Ståhl, G. [online]. 2002 [cited 12 February 2009]. Sweden's new national landscape monitoring program, SLÖ. Available from Internet: <http://www2.dmu.dk/1_Viden/2_Miljoetilstand/3_natur/nordlam/nldocs/wsNov01T3/PLofgren.pdf $>$.

Okoński, B. 2007. Hydrological response to land use changes in central European lowland forest catchments, Journal of Environmental Engineering and Landscape Management 15(1): 3-13.

Monitoring Information [online]. 2000 [cited 12 February 2009]. Workshop on Integration of Partial Coverage and Full Coverage Landscape. Available from Internet: $<$ http://www2.dmu.dk/1_Viden/2_Miljoe-tilstand/3_natur/ nordlam/NLpubl/wsOct00T2_rpt.pdf>.

Naveh, Z.; Liebermann, A. S. 1990. Landscape Ecology. Theory and Application. New York.

Peterseil, J.; Wrbka, Th.; Plutzar, Ch.; Schmitzberger, I.; Kiss, A.; Szerencsits, E.; Reiter, K.; Schneider, W.; Suppan, F.; Beissmann, H. 2004. Evaluating the ecological sustainability of Austrian agricultural landscapes - the SINUS appro- 
ach, Land Use Policy 21(3): 307-320.

doi:10.1016/j.landusepol.2003.10.011

Roose, A.; Sepp, K.; Saluveer, E.; Kaasik, A.; Oja, T. 2007. Neighbourhood-defined approaches for integrating and designing landscape monitoring in Estonia, Landscape and Urban Planning 79: 177-189. doi:10.1016/j.landurbplan.2006.02.004

Smith, G. M.; Wyatt, B. K. 2007. Multi-scale survey by samplebased field methods and remote sensing: A comparison of UK experience with European environmental assessments, Landscape and Urban Planning 79: 170-176. doi:10.1016/j.landurbplan.2006.02.011
Sochava, V. B. 1978. Vvedenije v uchenije o geosistemakh [Introduction into the science of geosystems]. Novosibirsk (in Russian).

Veteikis, D.; Jankauskaite, M. 2006. Landscape negentropy as the measure of its stability in the context of sustainable development, in Citizens and Governance for Sustainable Development, CIGSUD-2006. Selected papers. Eds.: W. Leal Filho, D. Dzemydiene, L. Sakalauskas, E. Zavadskas. Vilnius, 300-304.

Wrbka, Th. [online] 2000 [cited 12 February 2009]. Landscape and Vegetation Monitoring in Austria. Available from Internet: <http://www2.dmu.dk/1_Viden/2_Miljoe-tilstand/ 3_natur/nordlam/NLmeetings/wsOct00T2.asp>.

\section{KRAŠTOVAIZDŽIO STEBĖSENOS VIETOS LYGMENIU ETALONŲ TERITORINIO IŠDE்STYMO PROBLEMA}

\section{Jankauskaitè, D. Veteikis}

Santrauka

Tvariajai plètrai planuoti tampa aktualia kraštovaizdžio kaitos stebėsena. Realūs kraštovaizdžio pokyčiai Lietuvos mastu turi būti fiksuojami stambiuoju masteliu (ne smulkesniu nei 1:10 000), vengiant nepageidautino smulkių kraštovaizdžio elementu generalizavimo. Tokiu masteliu racionalu būtų pokyčiu stebėjimus atlikti etalonuose, jų skaičius turètų būti statistiškai patikimas. Pateikiama originali kraštovaizdžio monitoringo etalonų išdèstymo Lietuvos teritorijoje metodika. Darbas buvo atliktas remiant Aplinkos apsaugos agentūrai prie Lietuvos aplinkos ministerijos. Metodika parengta atsižvelgiant ir į užsienio šalių patirtį. Pagal kraštovaizdžio tipu paplitimą proporcingai buvo išdalyta $1002,5 \mathrm{~km}^{2}$ ploto etalonu̧, papildomai koreguojant (padidinant) etalonu skaičių mažai paplitusiuose kraštovaizdžio tipuose (nerijoje, pajūrio lygumoje, deltoje). Taigi daugiausia etalonų (22) buvo skirta plačiausiai paplitusioms molingosioms lygumoms, mažiausiai (3) - pajūrio lygumai. Etalonams konkrečios vietos buvo parenkamos kompiuterine programa ir vadovautasi didžiausio reprezentatyvumo principu. Kiekvieno kraštovaizdžio tipo buvo išbandyta nuo kelių šimtų iki keliasdešimties tūkstančių galimų etalonų padèčių nustatyta pagal žemės dangos struktūrą reprezentuojančios geriausiai. Etalonų vietų parinkimas buvo siejamas ir su kraštovaizdžio buferiškumo cheminei taršai arealais, daugiau koncentruojant mažesnio buferiškumo (jautresniuose cheminei taršai) plotuose.

Reikšminiai žodžiai: kraštovaizdžio monitoringas, stebėsenos etalonai, didžiausio atstovavimo principas, žemės dangos struktūra, gamtiniai kraštovaizdžio tipai.

\section{К ВОПРОСУ О ТЕРРИТОРИАЛЬНОМ РАСПРЕДЕЛЕНИИ ЭТАЛОННЫХ АРЕАЛОВ ДЛЯ ЛАНДШАФТНОГО МОНИТОРИНГА МЕСТНОГО УРОВНЯ}

\section{М. Янкаускайте, Д. Ветейкис}

Резюме

В настоящее время мониторинг изменений ландшафта становится актуальным для планировки сбалансированного развития. Реальные изменения ландшафта в Литве должны быть прослеживаемы в крупном масштабе (не мельче чем 1:10.000) во избежание нежелательной генерализации мелких структурных элементов ландшафта. В таком масштабе рационально осуществлять наблюдения на специально выделенных эталонных территориях, число которых должно быть статистически достаточным. В статье приведена методика расположения названных эталонов на территории Литвы. Работа выполнена при поддержке Агентства по охране окружающей среды при Министерстве окружающей среды. Методика разработана с учетом опыта зарубежных стран.

С учетом распределения ландшафтных типов пропорционально было поделено сто эталонов площадью 2,5 км² каждый. Дополнительно корректировалось (увеличивалось) число эталонов в мало распространенных ландшафтных типах (на косе, приморской равнине, в дельте). Наибольшее число эталонов (22) было отдано глинистым (наиболее распространенным) равнинам, а наименьшее (3) - приморской равнине.

С целью подбора для эталонов конкретных мест была применена компьютерная программа, а также следовали принципу наивысшей репрезентативности. В каждом ландшафтном типе было испробовано от нескольких сот до нескольких десятков тысяч возможных положений эталонов с целью определить лучшее положение по репрезентативности земельно покровной структуры. Подбор мест для эталонов был осуществлен с учетом сопротивляемости ландшафта химическому загрязнению. Больше эталонов размещалось в наименее устойчивых ареалах.

Ключевые слова: мониторинг ландшафта, эталонные ареалы, принцип наивысшей репрезентативности, структура земельного покрова, природные типы ландшафта.

Margarita JANKAUSKAITE். Dr, senior research worker and head of Dept of Landscape Geography and Cartography, Institute of Geology and Geography; Assoc. Prof., Vilnius University. Doctor of Natural Sciences (1986), First degree in Natural Sciences (1981), Vilnius University. Publications: author of over 50 scientific publications. Conferences: participant of over 50 international and national conferences. Research interests: landscape, landscape geochemistry, landscape ecology and landscape planning.

Darijus VETEIKIS. Assoc. Prof. of Vilnius University, Faculty of Natural Sciences. Doctor of Natural Sciences, 2003, Vilnius University, 2004. Publications: author of over 30 scientific publications. Conferences: participant of 12 international and national conferences. Research interests: landscape morphology, technogenic structure of landscape, cultural landscape. 